\title{
Kariyer Uyum Yeteneği Ölçeğinin Kültürlerarası Uyarlaması: Antalya' daki Beş Yıldızlı Otellerin Çalışanları Üzerinde Bir Uygulama \\ (Cross-Cultural Adaptation of the Career Adapt-Abilities Scale: An Application on the Employees of Five-Star Hotels in Antalya)
}

\section{Engin BAYRAKTAROĞLU (iD a Oktay EMIR iD b}

a Anadolu Üniversitesi, Turizm Fakültesi, Turizm İşletmeciliği Bölümü, Eskişehir, Türkiye. enginbayraktaroglu@anadolu.edu.tr

b Anadolu Üniversitesi, Açıöğretim Fakültesi, Uzaktan Öğretim Bölümü, Eskişehir, Türkiye. oktayemir@anadolu.edu.tr

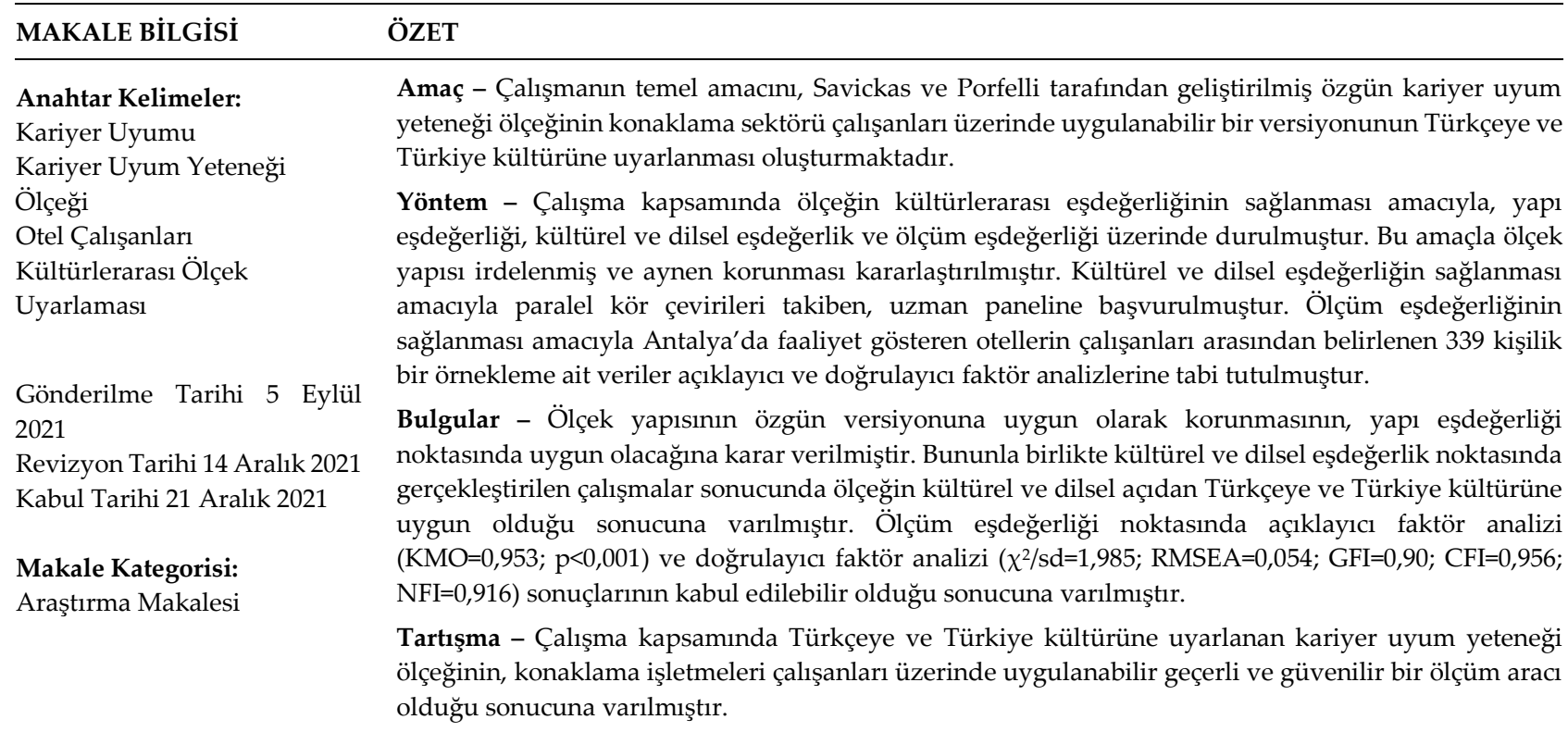

\section{ARTICLE INFO ABSTRACT}

\section{Keywords:}

Career Adaptability

Career Adapt-Abilities Scale

Hotel Employees

Intercultural Scale Adaptation

Received 5 September 2021 Revised 14 December 2021 Accepted 21 December 2021

\section{Article Classification:}

Research Article
Purpose - The study's primary goal is to adapt an applicable version of the original career adapt-abilities scale developed by Savickas and Porfelli to Turkish and Turkish culture.

Design/methodology/approach - Within the scope of the study, to ensure the intercultural equivalence of the scale, structural equivalence, cultural and linguistic equivalence and measurement equivalence were emphasized. For this purpose, the scale structure was examined, and it was decided to keep it. Following parallel blind translations, an expert panel was consulted to ensure cultural and linguistic equivalence. In order to provide measurement equivalence, the data of a sample of 339 people drawn from the employees of the hotels operating in Antalya were subjected to explanatory and confirmatory factor analysis.

Findings - It has been accepted that the preservation of the scale structure in accordance with the original version would be appropriate in terms of structural equivalence. In addition, as a result of the studies carried out at the point of cultural and linguistic equivalence, it was concluded that the scale is culturally and linguistically appropriate for the Turkish language and culture. At the point of measurement equivalence, it was concluded that the results of exploratory factor analysis $(\mathrm{KMO}=0.953$; $\mathrm{p}<0.001)$ and confirmatory factor analysis $\left(\chi^{2} / \mathrm{df}=1.985 ; \mathrm{RMSEA}=0.054 ; \mathrm{GFI}=0.90 ; \mathrm{CFI}=0.956\right.$; NFI=0.916) were acceptable.

Discussion - As a result, it was concluded that the career adapt-abilities scale, adapted to the Turkish language and culture, is a valid, reliable and applicable measurement tool to the employees of accommodation enterprises. 


\section{GİRIŞ}

İşletmelerin zaman içerisinde büyümeleri, çalıştıkları iş kollarını çeşitlendirmeleri ve gerçekleştirdiği yatay yahut dikey birleşmeler, yaşanan bu değişiklikleri yürütecek ya da bunlara uyum sağlayabilecek yönetici ve işgörenlere olan ihtiyacı arttırmaktadır (Taşlıyan, Arı ve Düzman, 2011). Bu durum çalışanların kendilerini geliştirmelerini, değişen iş dünyasına ve yeniliklere uyum sağlamalarını gerektirmektedir (Güney, 2014). Çalışanların, faaliyet gösterdikleri iş alanında kendilerini geliştirmelerini, tecrübe ve yetenek kazanmalarını içeren kariyer kavramı (Tortop vd., 2006: 174), bir yandan çalışanın kendisiyle ilişkiliyken, diğer yandan da işletmelerle ilişki halindedir (Yüksel, 2000: 23). Zira kariyer, çalışana psiko-sosyal yönden tatmin sağlarken (Uğur, 2008: 247), kabiliyetli çalışanlara kariyer yapma şansı vermek onları işletmede uzun süre tutmayı ve verimliliklerini arttırmayı sağlar (Yüksel, 2000: 24).

İş hayatında yaşanan değişken şartlar ve yeni gelişmeler, çalışanların geçmişe nazaran daha sık iş değiştirmelerine de yol açmaktadır (Savickas vd., 2009). Bu noktada değişen kariyer şartlarına uyum konusunda yetenekli olan bireylerin sektörler arası geçişlere ya da iş yeri değişikliklerine daha rahat uyum sağladıkları ve kısa zamanda daha kaliteli işler ortaya koyabildikleri düşünülmektedir (Tolentino vd., 2014: 40). Bu tarz değişimlere hızlı ve olumlu tepki vermeyi ifade eden kariyer uyumu; belirli ve tanımlı görevleri yerine getirmeye hazır olma, işyerinde verilen rolleri üstlenebilme, değişen çalışma koşullarının ortaya çıkardığı belirsizliğin üstesinden gelebilme ve öngörülemeyen şartlarla baş edebilme becerileri olarak tanımlanmaktadır (Savickas, 1997).

Kariyer uyum yeteneği (KUY) en geniş tanımıyla, bireylerin kariyerleri ve iş yaşamları içerisinde sahip olmaları gereken önemli yetkinlik ve becerileri içermektedir (Dufy, 2010: 420). Kariyer uyumu, küresel iş dünyasının ve kişisel yaşamın önemli bir yeteneğidir ve bu yetenek iş dünyasındaki değişimler ve bireylerin bu değişimlerle baş etme şekilleriyle ilgilidir (Hamtiaux, Houssemand ve Vrignaud, 2013: 130). Kariyer uyum yeteneği; bireylerin mesleki gerekliliklere hazırlanarak ve iş hayatına katılarak; iş koşullarındaki değişiklik ihtiyaçları karşılamaya hazır olmalarını içermektedir (Savickas, 1997). Bu bağlamda kariyer uyumu, bireyin karşılaşacağı mesleki görevleri, iş hayatındaki değişimleri ve stres kaynaklarını yönetebilmesi için gerekli olan becerilere sahip olma durumunu ve bu becerileri geliştirme noktasındaki yatkınlığını içeren bir yapıdır (Yousefi vd., 2011). Bireylerde kariyer uyumunun temelini, kariyer amaçlarının çevreden kaynaklanan fırsatlara ve tehditlere göre uyarlanması faaliyeti oluşturmaktadır (Hirschi ve Vondracek, 2009). Bu yaklaşım içerisinde kariyer uyum yeteneği, kariyer geliştirme faaliyeti ile bireylerin sosyal ve psikolojik durumu arasındaki uyum becerileri olarak tanımlanabilir (Skorikov, 2007: 10).

Kariyer uyum yeteneği, yetişkinlerin kariyer gelişiminde ilk kez Super ve Knasel (1981) tarafından kullanılmış ve bireylerin değişen işler ve çalışma koşullarına uyum sağlayabilme yeteneği şeklinde tanımlanmıştır. Savickas (1997: 254) ise kariyer uyum yeteneğini, bu yaklaşımlardan yola çıkarak, bireyin çalışma hayatında karşılaşacağı görevleri gerçekleştirmek amacıyla hazır olması ile, çalışma şartlarından kaynaklanan değişimlere uyum sağlayabilmesi becerisi olarak tanımlamaktadır. Günümüzün iş dünyasında meydana gelen ve bir süreklilik arz eden değişimler düşünüldüğünde, kariyer uyumu önemli bir beceri olarak kabul edilmektedir (Kalafat, 2012: 170-171). Kariyer uyum yeteneği yüksek olan bireylerin, gelecek planları üzerine ciddi şekilde kafa yordukları düşünülmektedir. Bununla birlikte bu tip bireylerin mesleki gelecekleri için kişisel gelişimlerine önem vermeleri ve bu doğrultuda araştırmalar yaparak kararlar almaları da önemli bir özellikleridir. Böylece iş hayatında karşılaşacakları olası durumlara karşı farkındalıkları yüksek bireyler olarak, problem çözme yeteneklerini ve kendilerini güvenlerini de arttırmaktadırlar (Ömeroğlu, 2014: 35).

Bu çalışma ile, yazında bireylerin değişen işler ve çalışma koşullarına uyum sağlayabilme yeteneği olarak tanımlanan kariyer uyum yeteneğinin ölçülmesini amaçlayan ölçekler arasında yaygın olarak kullanılan, Savickas ve Porfelli (2012) tarafından geliştirilen ölçeğin Türkçeye ve Türkiye kültürüne uyarlanması amaçlanmıştır. Bu bağlamda turizm endüstrisinin konaklama sektöründe faaliyet gösteren beş yıldızlı otel çalışanları üzerinde bir uygulama gerçekleştirilmiştir.

\section{YÖNTEM}

Bu bölümde araştırma yöntemi araştırmanın modeli, evren ve örneklem, veri toplama aracı ve verilerin analizi başlıkları altında sunulmuştur. Bir ölçek uyarlamasını içeren araştırma kapsamında kullanılan tekniklerin sunulduğu bu bölümü takiben, araştırmaya ilişkin bulgulara yer verilmiştir. 


\subsection{Araştırma Modeli}

Ölçüm aracının farklı kültürler arasında uyarlanması çabaları içinde en önemli konu ölçüm aracının kültürlerarası eşdeğerliğinin sağlanmasıdır. Yazında kültürlerarası eşdeğerlik problemi ve boyutları üzerinde duran kimi çalışmalar bulunmaktadır (bkz. Hui ve Triandis 1985; Herdman, Fox-Rushby ve Badia, 1997; Beaton, Bombardier, Guillemin ve Ferraz, 2000; Koller vd. 2007; Caramelli ve Van de Vijver 2013; Epstein, Santo ve Guillemin, 2015). Bu çalışmalar kapsamında incelenen eşdeğerlik boyutları Tablo-1'de görülmektedir.

Tablo 1. Yazında Kültürler-arası Eşdeğerlikler

\begin{tabular}{l|l}
\hline Yayın & Eşdeğerlik Boyutları \\
\hline Hui ve Triandis (1985) & $\begin{array}{l}\text { Kavramsal/İşlevsel eşdeğerlik, Yapı-işlem eşdeğerliği, Madde eşdeğerliği, } \\
\text { Ölçekleme eşdeğerliği }\end{array}$ \\
\hline Herdman vd. (1997) & $\begin{array}{l}\text { Ölçüt eşdeğerliği, Kavram eşdeğerliği, Madde eşdeğerliği, Kültürel } \\
\text { eşdeğerlik, Dil eşdeğerliği, Anlamın eşdeğerliği, Yapı-işlem eşdeğerliği, } \\
\text { Deyimsel eşdeğerlik, Yapı eşdeğerliği, Ölçüm eşdeğerliği, Deneyimsel } \\
\text { eşdeğerlik. }\end{array}$ \\
\hline Beaton vd. (2000) & $\begin{array}{l}\text { Semantik eşdeğerlik, Deyimsel eşdeğerlik, Deneyimsel eşdeğerlik, } \\
\text { Kavramsal eşdeğerlik. }\end{array}$ \\
\hline Koller vd. (2007) & $\begin{array}{l}\text { Semantik, Kavramsal, Yazım, Tutarlılık, Ölçekleme, Kültürel } \\
\text { çeşitlilik/uygunluk. }\end{array}$ \\
\hline Caramelli ve Van de Vijver (2013) & Yapı eşdeğerliği, Kültürel eşdeğerlik, Dilsel eşdeğerlik, Ölçüm eşdeğerliği. \\
\hline Epstein vd. (2015) & $\begin{array}{l}\text { Kavramsal eşdeğerlik, Semantik eşdeğerlik, Operasyonel eşdeğerlik, Ölçüm } \\
\text { eşdeğerliği, I̧şlevsel eşdeğerlik. }\end{array}$ \\
\hline
\end{tabular}

Bu çalışmada Caramelli ve Van de Vijver (2013) tarafından dört boyut altında değerlendirilmiş eşdeğerlik bakış açısından yola çıkılmıştır. Diğer bakış açılarından ziyade bunun seçilmesinin sebebi ortaya sadeleştirilmiş bir yapı koyarak uygulama açısından kolaylıklar sağlayacak olmasıdır. Şekil 1'de araştırma aşamaları görülmektedir.

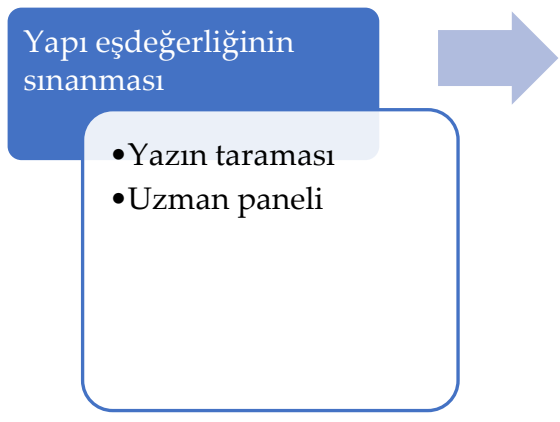

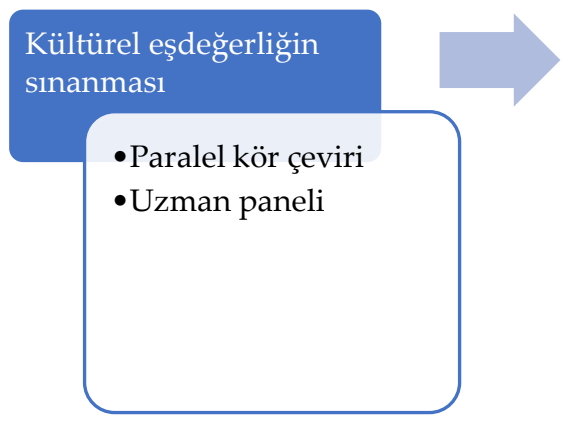

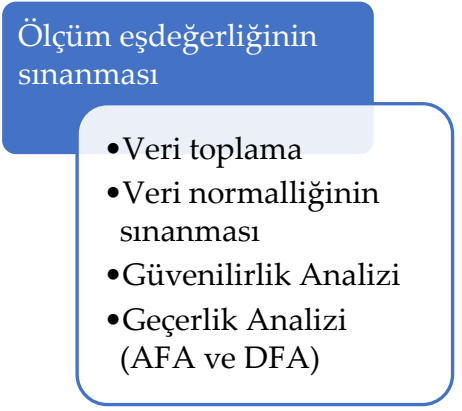

Şekil 1. Araştırma Aşamaları

$\mathrm{Bu}$ yöntemin boyutları incelenirse, yapı eşdeğerliği (kavramsal/işlevsel eşdeğerlik) kavramın tanımını, belirleyici unsurlarını, sonuçlarını ve ilişkilerini ele alır (Hui ve Triandis, 1985). Kültürel eşdeğerlik ise, ölçüm aracını oluşturan kaynak dildeki maddelerin, hedef kültüre uyumu ile ilgilenir. Bu noktada Brislin (1986), çevirmenlerin kaynak dilde yazılmış ilgili maddelerin ne demek istediğini ve bu isteğin hedef kültürdeki karşılığını kesinlikle anlamaları gerektiğinden bahsetmektedir. Kültürel eşdeğerlik altında ölçüm aracının semantik ve deyimsel açıdan da incelenmesinde fayda vardır. Dilsel eşdeğerlik (çeviri eşdeğerliği) ise, ölçüm aracında kullanılan maddelerin kaynak dilden hedef dile uyarlanmasında dilbilgisi, yazım kuralları, kelime ve anlam gibi değişkenleri konu edinir. Ölçüm eşdeğerliği ise, ölçüm aracının kaynak topluluk ile hedef topluluk üzerinde verdiği sonuçların eşdeğerliğini içerir. Bu noktada yapı geçerliği, güvenirlik ve ölçek geçerliğine dair sonuçlar karşılaştırılır ve yorumlanır. Bu çalışma kapsamında araştırma deseni yapı eşdeğerliğini inceleyen bir aşama, kültürel ve dilsel eşdeğerliği değerlendiren ortak bir aşama ve ölçüm eşdeğerliğini ele alan bir aşama olmak üzere üç aşama altında oluşturulmuştur. 


\subsubsection{Yapı Eşdeğerliği}

Çalışma kapsamında Savickas ve Porfelli (2012) tarafından geliştirilen kariyer uyum yeteneği ölçeği ele alınmıştır. Bu ölçekte kariyer uyum yeteneği faktörleri ilgi, sorumluluk, merak ve güven olmak üzere dört boyutta incelenmiştir.

İlgi faktörü, bireylerin mesleki yaşamları içerisinde ihtiyaç duyacakları becerilere ilişkin farkındalıklarını ve bu becerileri geliştirme noktasındaki planlama becerilerini ölçmeyi amaçlamaktadır. Bu faktör, bireyin mesleki geleceğiyle ilgili olduğu, geleceği üzerine düşündüğü, ilk ve en önemli boyuttur. İlgi faktörü, bireylerin iş tecrübeleri, mevcut iş ve pozisyonları ve gelecekte sahip olmak istedikleri iş ile ilgili konular üzerine düşünmelerini içermektedir (Savickas, 2005). Geleceğe yönelik endişe duymayı da içeren ilgi faktörü, bireyin gelecekte karşılaşacağı kariyer değişimlerine yoğunlaşmasını ve bunlara hazırlanmasını ifade etmektedir (Savickas ve Portfeli, 2012).

Sorumluluk faktörü, bireylerin mesleki gelişimleri üzerine karar alma ve bu gelişimi yönetebilme sorumluluğuna sahip olup olmama durumunu ölçmeyi amaçlamaktadır. Bireylerin kendi mesleki gelecekleri çerçevesinde sorumluluk almaları ve bunun kontrolünün ellerinde olduğunu hissetmeleri, kariyer uyumunun ikinci en önemli boyutudur (Savickas, 2005). Bu faktör bireylerin kariyer gelişimini, içinde bulunduğu durumlara ve çevresine bağlamak, bunlardan şikâyet etmek yerine, sorumluluk alarak kariyer gelişimine ilişkin çaba göstermeyi içermektedir (Savickas ve Porfeli, 2012).

Merak faktörü, bireylerin mesleki anlamda kendisini ilgilendiren çevresel değişkenleri öğrenmeye ilişkin sahip olması gereken araştırma dürtüsünü ölçmeyi amaçlamaktadır. Bu faktör, bireyin önünde yer alan iş fırsatları hakkındaki bilgi edinme çabalarını içermektedir. Merak kavramı bireylerin kendi becerileri, içerisinde yer aldıkları iş çevresi ve bu çevredeki fırsatlar ve tehditler konusundaki merakı ve öğrenmeye olan açıklı̆̆ ifade etmektedir (Savickas, 2005). Bir başka tanımıyla merak faktörü, bireyin kariyeriyle ilişkili çeşitli durumlarda ve bu durumlarda ortaya çıkabilecek değişimlerde kendilerinin üstlenebilecekleri rolleri araştırmasıdır (Savickas ve Porfeli, 2012).

Güven faktörü, bireylerin gelecekte ihtiyaç duyacağı mesleki gereklilikler ve problem çözme becerilerine ilişkin kendilerine duydukları güveni ölçmeyi amaçlamaktadır. Bu faktörün temeli bireylerin iş dünyasında karşılaşacakları zorluklarla ve engellerle başa çıkma konusunda kendilerine yönelik duydukları güven duygusuna dayanmaktadır. Zira bireylerin iş yaşamında karşılaştığı problemlerle başa çıkmasının birinci koşulunun kendilerine duydukları güven olduğu belirtilmektedir (Savickas 2005). Kariyer güveni, günlük aktivitelerde karşılaşılan problemlerin üstesinden gelinerek gelişen bir beceri olarak ele alınmaktadır. Bu tarz görevleri başarıyla gerçekleştiren bireylerin benlik saygısının arttığı, ayrıca günlük faaliyetlerle ilgili bilgi toplama ve keşif girişimleri ile kendine güvenin geliştiği düşünülmektedir (Savickas ve Porfeli, 2012).

Bu çalışma kapsamında ele alınan ölçüm aracı ve ölçtüğü kavramsal yapının değiştirilmeden kullanılması hedeflenmektedir. Bu açıdan bakıldığında yapısal açıdan bir eşdeğerlik sorunu ile karşılaşılmayacağı öngörülmüş̧ür.

\subsubsection{Kültürel ve Dilsel Eşdeğerlik}

Yazında, üzerinde anlaşılmış tek bir ortak teknik olmasa da geri-çeviri ve paralel kör çeviri teknikleri dilsel ve kültürel eşdeğerliğin sağlanmasında en çok kullanılan tekniklerden ikisidir. Geri-çeviri tekniğinde bir çevirmen ölçüm aracını kaynak dilden, hedef dile çevirdikten sonra diğeri bu çevrilen aracı, kaynak dildeki sürümünü görmeden geri çevirmektedir. Bu süreç ölçüm aracının nihai haline karar kılınana kadar farklı kişiler ile tekrarlanmaktadır. Bu tekniğin en çok eleştirilen kısmı, geri-çeviriyi gerçekleştiren "iyi" çevirmenlerin, kaynak dilden yapılan ilk çevirideki hataları istemeden de olsa giderebileceği olasılığıdır. Paralel kör çeviri ise metnin kaynak dilden, birden çok çevirmen tarafından ve birbirlerinden bağımsız olarak hedef dile çevrilmesine dayanmaktadır. Daha sonrasında yapılan bu çeviriler bir araya getirilmekte ve üzerinde tartışılarak nihai sürüme ulaşılmaktadır (Harkness 2003; Usunier 2011; Caramelli ve Van de Vijver 2013). Geri-çeviri ya da yapılan çevirilerin bir değerlendirme grubunun önüne sunulması çokça rastlanan teknikler olmasına rağmen, yazında Perneger, Leplège ve Etter (1999) ile Falcão, Ciconelli ve Ferraz (2003) gibi kimi araştırmacıların bu süreci geri çeviri ya da deneme grubu kullanmadan sonuçlandırmış olduğu da görülmektedir. Bu noktada genel geçer bir standardın bulunmadığı da yine kabul edilen bir olgudur (Van de Vijver 2013; Epstein vd. 2015). 
Bu çalışma kapsamında tek bir tekniğe bağlı kalınmamış ve çeşitli teknikler bir arada kullanılmıştır. Yazında geri-çeviri ile ilgili eleştiriler göz önüne alınarak geri-çeviri tekniği kullanılmamış bunun yerine ilk olarak iki uzman tarafından paralel kör çeviri yapılmıştır. Bu çevirileri yapan uzmanlar turizm işletmeciliği alanında doktora derecesine sahiptir. Daha sonrasında bu paralel kör çeviriler bir araya getirilmiş ve ortak bir çeviri sürümü oluşturulmuştur. Ortak sürüm ortaya çıtıktan sonra ölçeğin özgün dildeki sürümü, paralel kör çevirilerden sonra ortaya çıkan sürümleri ve bu sürümlerin birleştirilerek oluşturulan ortak sürümü üç uzmandan oluşan bir grup tarafından değerlendirilmiştir. Bu uzmanların ikisi turizm işletmeciliği alanında doktora derecesine birisi ise turizm işletmeciliği alanında yüksek lisans derecesine sahiptir. Bu uzmanlar ile gerçekleştirilen toplantıda ölçeğin hedef dildeki nihai sürümü oluşturulmuştur (Ek 1).

\subsection{3. Ölçüm Eşdeğerliği}

Bu çalışma kapsamında üçüncü aşama olarak, Türkçeye uyarlanan KUY ölçeğinin, ölçüm eşdeğerliği sınanmıştır. Ölçüm eşdeğerliğinin sınanması, ölçüm aracının kaynak topluluk ile hedef topluluk üzerinde verdiği sonuçların karşılaştırılarak eşdeğerliğinin incelenmesini içermektedir. Bu noktada güvenirlik ve geçerliğe dair sonuçlar karşılaştırılır ve yorumlanır. Bu çalışmada öncelikli olarak verinin normalliği sınanmış, sonrasında ölçeğe ilişkin güvenilirlik analizi sonuçları incelenmiştir. Son olarak ölçeğin geçerliğinin sınanması için sırasıyla AFA ve DFA uygulanmıştır. Ölçüm eşdeğerliğine ilişkin adımların detayı, verilerin analizi başlı̆̆ı altında detaylı şekilde sunulmuştur.

\subsection{Veri Toplama Aracı}

Bu çalışma kapsamında Savickas ve Porfelli (2012) tarafından geliştirilen kariyer uyum yeteneği ölçeği Türkçeye çevrilmiş ve ölçeğin kültürlerarası uyarlaması yapılarak, turizm endüstrisinde faaliyet gösteren bireyler üzerinde uygulaması gerçekleştirilmiştir. Çalışma kapsamında ele alınan ölçeğin özgün sürümü "Savickas, M.L. ve Porfelli, E.J. (2012). Career Adapt-Abilities Scale: Construction, reliability, and measurement equivalence across 13 countries. Journal of Vocational Behaviour, 80, 661-673" künyesiyle yayınlanmıştır. Bu kapsamda bireylerin kariyer uyum yeteneğini ölçmesi amaçlanan ölçek, dört boyut ve 24 maddeden oluşmaktadır. Altı maddeden oluşan ilgi (i) adlı boyut ile bireylerin mesleki yaşamları içerisinde ihtiyaç duyacakları becerilere ilişkin farkındalıklarının ve bu becerileri geliştirme noktasındaki planlama becerilerinin; altı maddeden oluşan sorumluluk (s) adlı boyut ile bireylerin mesleki gelişimleri üzerine karar alma ve bu gelişimi yönetebilme sorumluluğuna sahip olup olmama durumunun; altı maddeden oluşan merak (m) adlı boyut ile bireylerin mesleki anlamda kendisini ilgilendiren çevresel değişkenleri öğrenmeye ilişkin sahip olması gereken araştırma dürtüsünün; altı maddeden oluşan güven (g) adlı boyut ile bireylerin gelecekte ihtiyaç duyacağı mesleki gereklilikler ve problem çözme becerilerine ilişkin kendilerine duydukları güvenin ölçülmesi amaçlanmaktadır. Özgün ölçeğe ilişkin analizler 13 ülkeyi temsil eden farklı örneklemler ile gerçekleştirilmiştir. Özgün ölçeğin AFA sonuçları şu şekildedir (Tablo 2);

Tablo 2. Özgün KUY ölçeğine ilişkin AFA sonuçları

\begin{tabular}{lccc}
\hline Faktör & Faktör Yükü & $\boldsymbol{\sigma}$ & $\boldsymbol{\alpha}$ \\
\hline İlgi & 0,78 & 0,01 & 0,83 \\
Sorumluluk & 0,86 & 0,01 & 0,74 \\
Merak & 0,88 & 0,02 & 0,79 \\
Güven & 0,90 & 0,01 & 0,85 \\
\hline
\end{tabular}

\subsection{Evren ve Örneklem}

Çalışma kapsamında araştırma evreni, Antalya ili sınırları içerisinde faaliyet gösteren beş yıldızlı otel çalışanlarının her biri olarak belirlenmiştir. Araştırma evreninin sayısal sınırları tam olarak bilinmemekle birlikte, veri toplama dönemi olarak Akdeniz Bölgesinde yoğun turizm sezonu olarak kabul edilen mayıs ile ekim ayları arasının uygun olacağı öngörülmüştür. Çalışma kapsamında ihtiyaç duyulan verilerin toplanması amacıyla, 2019 yılının haziran ayı ile eylül ayı arasındaki dört aylık dönemde sahaya çıkılmıştır. İhtiyaç duyulan veriler yüz yüze anket yöntemi ile toplanmış ve anket yapılacak çalışanlar olasılık dışı örnekleme yöntemlerinden uygun örnekleme yöntemiyle belirlenmiştir (Balcı, 2013: 103). Yapılan saha çalışması sonucunda 366 otel çalışanına soru formu uygulanmış ve bu sayı yeterli bulunarak çalışma sonlandırılmıştır. Elde edilen soru formlarının $24^{\prime}$ ü eksik veriler ve tutarsız cevaplar göz önüne alınarak araştırmadan 
çıartılmış ve 342 soru formu analize alınmıştır. Birinci aşama analizlerde üç soru formu daha, içerdiği tutarsız veriler dolayısıyla araştırmadan çıkarılmıştır. Böylece 339 otel çalışanına ait formlar, nihai analize alınmıştır.

\subsection{Verilerin Analizi}

Bu çalışmada KUY ölçeğinin Türkçeye uyarlanması amacıyla öncelikli olarak toplanan verinin normalliği sınanmış, sonrasında ölçeğe ilişkin güvenilirlik analizi sonuçları incelenmiştir. Son olarak ölçeğin geçerliğinin sınanması için sırasıyla AFA ve DFA uygulanmıştır. Bu adımlara ilişkin detaylı açıklamalar devam eden başliklarda sunulmuştur.

\subsubsection{Verinin Normalliği}

Veri dağılımının normal olup olmadığı grafikler ve istatistiksel tekniklerle test edilebilir. Histogram, dalyaprak grafiği, kutu-bıyık grafiği, P-P grafiği ve Q-Q grafiği aracılığıyla veri setinin normal dağılıma sahip olduğu incelenebilmektedir. Bununla birlikte, ki-kare uygunluk testi, Shapiro-Wilks Testi, Lilifors Testi, Kolmogrov-Smirnov Testi ve Anderson-Darling testiyle de veri setinin normal dağılıp dağılmadığı sınanabilmektedir (Gürsakal, 2009: 266). Sosyal bilimlerde verinin normal dağılıp dağılmadığına yönelik testler son dönemde yerini çarpıklık ve basıklık değerlerinin incelenmesine bırakmıştır. Çarpıklık ve basıklık değerleri incelemesinde Tabachnick ve Fidell (2013), bu değerlerin $+1,5$ ile $-1,5$ aralığında bulunmasının normal dağılıma işaret ettiğini belirtmektedirler. Bununla birlikte gerekli durumlarda +2 ile -2 aralığında yer alan çarpıklık ve basıklık değerlerine sahip verilerin de normal dağılıma sahip olduğunun kabul edilebileceğini belirten çalışmalar da mevcuttur (George ve Mallery, 2010). Çalışma kapsamında Tabachnick ve Fidell'in (2013) normallik varsayımı benimsenmiştir.

\subsubsection{Güvenirlik Analizi}

Güvenilirlik, bir ölçüm aracının içerik, yapı ve araştırılan fenomeni sorgulama gücünü ifade eden bir kavramdır. Bir güvenilirlik sınama yöntemi olan ve bu çalışma kapsamında da kullanılan Cronbach'ın $\alpha$ katsayısı ölçeğin genel güvenilirliğini sınayan bir parametredir. Cronbach'ın $\alpha$ katsayısı ile ölçekte yer alan $\mathrm{k}$ sayıda ifadenin türdeş bir yapıyı sorgularken bir bütün oluşturup oluşturmadığını sınanır. Ölçeğin güvenilirliğini yorumlamaya yarayan $\alpha$ katsayısı değerlendirilirken kimi araştırmacılar 0 ile 0,40 aralığındaki değerler ölçeğin güvenilir olmadığını, 0,40 ile 0,60 arasındaki değerler ölçeğin düşük güvenilirliğe sahip olduğunu, 0,60 ile 0,80 arasındaki değerler ölçeğin güvenilir olduğunu ve 0,80 ile 1 aralığındaki değerlerin ölçeğin yüksek güvenilirliğe sahip olduğunu ifade etmektedir (Özdamar, 2011: 603 - 606). Kimi başka araştırmacılar ise $\alpha$ katsayısını incelerken 0,50'nin altında yer alan değerlerin, ölçeğin güvenilir olmadığına, 0,50 ile 0,60 aralığındaki değerlerin zayıf, 0,60 ile 0,70 aralığındaki değerlerin sorgulanabilir, 0,70 ile 0,80 aralığındaki değerlerin kabul edilebilir, 0,80 ile 0,90 aralığındaki değerlerin iyi ve 0,90 ile 1 aralığındaki değerlerin ise mükemmel güvenilirliği ifade ettiğini kabul etmektedir (Gliem ve Gliem, 2003).

\subsubsection{Geçerlik Analizi}

Geçerlik, bir ölçüm aracının içeriğini ve ölçmeye talip olduğu yapıyı ne derecede ölçtüğünün tayin edilmesini ifade eden bir kavramdır (Balc1, 2013: 117). Araştırmalarda kapsam geçerliğini test etmek amacıyla faktör analizi sıklıkla kullanılan bir yöntemdir. Bu kapsamda iki tip faktör analizinden bahsedilebilir. Bunların birincisi açıklayıcı faktör analizi (AFA), ikincisi ise doğrulayıcı faktör analizidir (DFA). Devam eden bölümde bu yöntem açıklanmıştır.

\subsubsection{Açıklayıcı Faktör Analizi}

AFA'da araştırmacı bir dizi değişken için, değişkenler arasındaki ilişkileri açıklamak üzere, temel faktörlerin neler olduğunu keşfetmeye çalışmaktadır (Mulaik, 2010: 427). Çalışma kapsamında AFA gerçekleştirilirken, en büyük benzerlik yöntemi seçilmiştir. En büyük benzerlik yöntemi hesaplanan en yüksek yük değerleri olasılığında, evren için faktör yüklerini tahmin etmeye yarayan bir yöntemdir (Tabachnick ve Fidell, 2013). Bu yöntemin uygulanması için çok değişkenli normallik varsayımının sağlanması yani, analizde kullanılan değişkenlere ait çarpıklık değerlerinin 2' den, basıklık değerlerinin ise $7^{\prime}$ den büyük olmaması beklenmektedir (Şencan, 2005). Bu yöntemin seçilmesinin sebebi DFA'da da sıklıkla kullanılıyor oluşu ve DFA'nın gerçekleştirileceği AMOS yazılımında da varsayılan olarak bu istatistiğin kullanılıyor oluşudur (Yaşlığlu, 2017: 78). Böylece AFA ve DFA sonuçları arasında uyum sağlanması amaçlanmıştır. 
Çalışmada faktör döndürme tekniği olarak Kaiser normalizasyonuyla oblimin tekniği seçilmiştir. Bunun sebebi AFA ile elde edilmesi öngörülen faktörlerin aynı yapı içerisinde bulunmaları ve birbirlerine yakın kavramları ölçüyor olmaları sebebiyle korelasyonlarının 0,30'dan yüksek olacağı öngörülmüş olmasıdır (Tabachnick ve Fidell, 2013). Faktör döndürme matematiksel bir işlemdir ve faktörlere ait varyans, kovaryans ya da korelasyon matrislerini değiştirmemektedir. Faktör döndürmesi ile her tür faktöre ilişkin ağırlıklı olan değişkenlerin belirgin şekilde ortaya çıkması sağlanmaktadır (Özdamar, 2010: 241).

AFA'da Kaiser-Meyer-Olkin (KMO) testi örneklem büyüklüğünün, ölçülmesi amaçlanan yapıyı ölçme noktasındaki yeterliliğini sınayan bir testtir. KMO değerinin 0,80 ile 1 aralığında olması örneklemin faktörlerin tahmini noktasında çok iyi düzeyde olduğunu, 0,50 ile 0,80 arasında olması da yeterli düzeyde olduğunu ifade etmektedir (Büyüköztürk, 2002; Hair, Black, Babin ve Anderson, 2010). Bartlett küresellik testiyle ise, değişkenlerin yapı içerisindeki tutarlılığı sınanmaktadır (Pett, Lackey ve Sullivan, 2003). Barlett testinin istatistiki olarak anlamlı $(\mathrm{p}<0,001)$ olması beklenmektedir (Büyüköztürk, 2002). AFA'nın kabul edilebilir olduğunu gösteren bir diğer önemli kriter ise varyansı açılama oranıdır. Toplam varyansın \%50'sini açıklanmış olması, analizin kabul edilebilir olduğunu göstermektedir. Bununla birlikte AFA'da özdeğeri 1'in altında kalan faktörler analizden çıarılmaktadır (Yaşlığlu, 2017: 77).

\subsubsection{Doğrulayıcı Faktör Analizi}

Sosyal bilimler alanındaki araştırmalarda daha güçlü güvenilirlik ve geçerlilik katsayılarına sahip ölçeklere ihtiyaç duyulmaktadır. Bunun en önemli nedenlerinden bir tanesi ölçülen olgunun büyük ölçüde soyut olmasıdır. Örneğin fen bilimlerinde ölçümlerin deneysel yöntem yardımıyla daha somut sonuçlarına ulaşmak mümkündür. Ancak sosyal bilimler alanında ölçümlerin gözle görülür sonuçlarına ulaşmak neredeyse imkânsızdır.

Psikometrik etki bırakan ölçeklerin geliştirilmesi zaman ve maliyet açısından külfetli süreçleri de beraberinde getirmektedir. Araştırmacılar çoğu zaman yeni bir ölçek geliştirecek zamana ve kaynağa sahip olamamaktadır. Bu nedenle zamandan ve maliyetten tasarruf sağlamak amacıyla birden fazla çalışmada kullanılmış ve test edilmiş olan mevcut ölçeklerin kullanılması, araştırmaları karşılaştırabilir hale getirmektedir. Bunu yapabilmek için öncelikle seçilen ölçeğin araştırmaya uygunluğu test edilmelidir. DFA, orijinal ölçeğin yeni veri setinde ne kadar iyi çalışacağını belirlemek amacıyla kullanılabilir (Harrington, 2009: $5)$.

DFA yardımıyla araştırmacı hipotezlerden yola çıkarak temel faktörlerin neler olduğunu ve gözlenen değişkenlerle ilişkisini anlamaya çalışır (Mulaik, 2010: 427). DFA'da araştırmacı bir dizi ölçeğin kapsamında yer alan faktörlerin sayısı ve ölçeğin hangi faktörleri temsil ettiği ile ilgili belirli bir öngörüye sahiptir. DFA aynı zamanda, faktörlerin sayısını ve türünü ifade eden hipotezlerin belirlenen veri setine uygulanıp uygulanamayacağını belirlemek amacıyla kullanılmaktadır. Araştırmada kullanılan hipotezlerin teorik temellere, büyük ölçüde de önceki çalışmalarda belirlenmiş teorik yapıya oturtulmuş olması gerekmektedir. Bu sayede DFA, araştırma problemleri ile ilgili daha güçlü sonuçlar elde etmeyi sağlamaktadır (Russell, 2002: 1638; Dwyer, Gill and Seetaram, 2012: 185). Bu nedenle, DFA'nın AFA kullanılarak yapılan ampirik analizler yardımıyla araştırmada kurgulanan yapı oluşturulduktan sonra, ölçek geliştirmenin ya da yapı geçerliliğinin sonraki safhalarında kullanıldığı ifade edilebilir (Brown, 2015: 35).

DFA'da, sınanmak istenen ölçeğin veri seti tarafından doğrulanıp doğrulanmadığının belirlenmesi için uyum endeksleri incelenmektedir (Bentler ve Yuan, 1999). Bu bağlamda incelenen parametreler arasında $\chi^{2} /$ serbestlik derecesi (sd), tahmin hatalarının ortalamasının karekökü (RMSEA), iyilik uyum endeksi (GFI), düzeltilmiş iyilik uyum endeksi (AGFI), standartlaştırılmış hata kareleri ortalamasının karekökü (SRMR), karşılaştırmalı uyum endeksi (CFI), göreli uyum endeksi (RFI), fazlalık uyum endeksi (IFI), normlaştırılmış uyum endeksi ya da Tucker-Lewis testi (TLI), sıkı normlaştırılmış uyum endeksi (PNFI), sıkı iyilik uyum endeksi (PGFI) sayılabilir (İlhan ve Çetin, 2014: 34). Tablo 3'te bu parametrelere ilişkin kabul edilen değerlere yer verilmiştir. 
E. Bayraktaroğlu - O. Emir 13/4 (2021) 3873-3888

Tablo 3. Uyum Endekslerine İlişkin Ölçütler

\begin{tabular}{lcc}
\hline Uyum Endeksi & Çok İyi Uyum & Kabul Edilebilir Uyum \\
\hline$\chi^{2} /$ sd & $0 \leq \chi^{2} / \mathrm{sd} \leq 2$ & $2 \leq \chi^{2} / \mathrm{sd} \leq 3$ \\
AGFI & $0,90 \leq \mathrm{AGFI} \leq 1$ & $0,85 \leq \mathrm{AGFI} \leq 0,90$ \\
GFI & $0,95 \leq \mathrm{GFI} \leq 1$ & $0,90 \leq \mathrm{GFI} \leq 0,95$ \\
CFI & $0,95 \leq \mathrm{CFI} \leq 1$ & $0,90 \leq \mathrm{CFI} \leq 0,95$ \\
NFI & $0,95 \leq \mathrm{NFI} \leq 1$ & $0,90 \leq \mathrm{NFI} \leq 0,95$ \\
TLI & $0,95 \leq \mathrm{TLI} \leq 1$ & $0,90 \leq \mathrm{TLI} \leq 0,95$ \\
RFI & $0,95 \leq \mathrm{RFI} \leq 1$ & $0,90 \leq \mathrm{RFI} \leq 0,95$ \\
IFI & $0,95 \leq \mathrm{IFI} \leq 1$ & $0,90 \leq \mathrm{IFI} \leq 0,95$ \\
RMSEA & $0 \leq \mathrm{RMSEA} \leq 0,05$ & $0,05 \leq \mathrm{RMSEA} \leq 0,08$ \\
SRMR & $0,00 \leq \mathrm{SRMR} \leq 0,05$ & $0,05 \leq \mathrm{SRMR} \leq 0,10$ \\
PNFI & $0,95 \leq \mathrm{PNFI} \leq 1$ & $0,50 \leq \mathrm{PNFI} \leq 0,95$ \\
PGFI & $0,95 \leq \mathrm{PGFI} \leq 1$ & $0,50 \leq \mathrm{PGFI} \leq 0,95$ \\
\hline
\end{tabular}

Kaynak: İlhan ve Çetin, 2014: 34

\section{BULGULAR}

Bu bölümde, bir önceki bölümde ölçüm eşdeğerliği başlığı altında detaylarına yer verilen analizlerin sonuçları sırasıyla sunulmuştur. Bu bağlamda önce veri dağılımının normalliği incelenmiş, sonrasında güvenilirlik analizleri gerçekleştirilmiştir. Güvenilirlik analizlerini takiben ise önce AFA, sonra da DFA gerçekleştirilmiştir.

\section{1. Örnekleme İlişkin Demografik Bulgular}

Araştırma kapsamında Antalya'da faaliyet gösteren beş yıldızlı otellerde görev yapan 339 çalışana ilişkin veriler, uygun örneklem yöntemiyle toplanmıştır. Bu bağlamda örnekleme ilişkin demografik bulgular Tablo 4 'te sunulmuştur.

Tablo 3. Örnekleme ilişkin demografik bulgular

\begin{tabular}{|c|c|c|c|c|}
\hline Değişken & Seçenek & Frekans & $\%$ & n \\
\hline \multirow{5}{*}{ Yaş } & $17-23$ & 45 & 13,3 & \multirow{5}{*}{339} \\
\hline & $24-29$ & 72 & 21,2 & \\
\hline & $30-34$ & 63 & 18,6 & \\
\hline & $35-39$ & 67 & 19,8 & \\
\hline & 40 ve üzeri & 92 & 21,1 & \\
\hline \multirow{3}{*}{ Cinsiyet } & Kadın & 144 & 42,5 & \multirow{3}{*}{339} \\
\hline & Erkek & 167 & 49,3 & \\
\hline & Belirtmek istemiyorum & 28 & 8,2 & \\
\hline \multirow{6}{*}{ Mezuniyet } & İlkokul & 35 & 10,3 & \multirow{6}{*}{339} \\
\hline & Ortaokul & 45 & 13,3 & \\
\hline & Lise & 138 & 40,7 & \\
\hline & Önlisans & 59 & 17,4 & \\
\hline & Lisans & 46 & 13,6 & \\
\hline & Lisansüstü & 16 & 4,7 & \\
\hline \multirow{4}{*}{ İşletmede Çalışma Süresi } & $0-1$ y1l & 67 & 19,8 & \multirow{4}{*}{339} \\
\hline & $2-3$ y1l & 152 & 44,8 & \\
\hline & $4-6$ y1l & 104 & 30,7 & \\
\hline & 7 yıl ve üzeri & 16 & 4,7 & \\
\hline \multirow{4}{*}{$\begin{array}{l}\text { Konaklama Sektöründeki } \\
\text { Mesleki Tecrübe }\end{array}$} & $0-5$ y1l & 94 & 27,7 & \multirow{4}{*}{339} \\
\hline & $6-9$ y1l & 80 & 23,6 & \\
\hline & $10-14$ yıl & 84 & 24,8 & \\
\hline & 15 yıl ve üzeri & 81 & 23,9 & \\
\hline
\end{tabular}

Örnekleme dâhil olan çalışanların en gencinin 17 yaşında en yaşlısının 60 yaşında olduğu görülmüştür. Çalışanların 144'ü kadın, 167'si erkektir. Çalışanların 138 kişiyle, yoğunluklu olarak lise mezunu olduğu saptanmıştır. Çalışanların yaklaşık \%75'inin 2 ile 6 yıldır işletmede çalışmakta olduğu saptanmıştır. 
E. Bayraktaroğlu - O. Emir 13/4 (2021) 3873-3888

Örnekleme dahil olan çalışanların konaklama sektöründe edindikleri mesleki tecrübenin yaşları ile orantılı şekilde dağıldığı saptanmıştır.

\subsection{Verinin Normalliğine İlişkin Bulgular}

Bu çalışmada verinin normal dağılıp dağılmadığının tespiti için çarpıklık ve basıklık değerleri incelenmiştir (Tablo 5). Çarpıklık ve basıklık değerlerinin incelenmesinde $+1,5$ ile $-1,5$ aralığı referans değerler olarak kabul edilmiştir (Tabachnick ve Fidell, 2013). Maddelere ilişkin değerlerin bu referans aralığın içerisinde yer aldı̆̆ı görülmektedir. Bu bağlamda analiz için kullanılacak veri setinin normal dağılıma sahip olduğu kabul edilmiştir.

Tablo 4. Maddelere ait çarpıklık ve basıklık değerleri

\begin{tabular}{lll|lll}
\hline Madde & Çarp1klık & Bas1klık & Madde & Çarp1kl1k & Basıklık \\
\hline i1 & $-0,759$ & $-0,082$ & $\mathbf{m 1 3}$ & $-0,827$ & 0,084 \\
i2 & $-0,993$ & 0,449 & $\mathbf{m 1 4}$ & $-0,709$ & $-0,342$ \\
i3 & $-0,763$ & 0,036 & $\mathbf{m 1 5}$ & $-0,894$ & 0,288 \\
i4 & $-0,842$ & 0,150 & $\mathbf{m 1 6}$ & $-0,850$ & 0,098 \\
i5 & $-0,498$ & $-0,786$ & $\mathbf{m 1 7}$ & $-0,869$ & 0,011 \\
i6 & $-0,818$ & 0,149 & $\mathbf{m 1 8}$ & $-0,825$ & 0,180 \\
s7 & $-1,170$ & 0,984 & $\mathbf{g 1 9}$ & $-1,139$ & 0,440 \\
s8 & $-1,180$ & 0,665 & $\mathbf{g 2 0}$ & $-1,255$ & 1,368 \\
s9 & $-1,208$ & 0,831 & $\mathbf{g 2 1}$ & $-1,069$ & 1,021 \\
s10 & $-1,183$ & 0,939 & $\mathbf{g 2 2}$ & $-0,953$ & 0,173 \\
s11 & $-1,143$ & 0,509 & $\mathbf{g 2 3}$ & $-0,951$ & $-0,101$ \\
s12 & $-0,898$ & $-0,097$ & g24 & $-1,175$ & 0,821 \\
\hline
\end{tabular}

Bu çalışma kapsamında çarpıklık ve basıklık değerlerinin incelenmesinde $+1,5$ ile $-1,5$ aralığı referans değerler olarak kabul edilmiştir. Bu bağlamda Tablo 5 incelendiğinde maddelere ilişkin değerlerin bu referans aralığ1 içerisinde yer aldığı görülmektedir. Bu bağlamda analiz için kullanılacak veri setinin normal dağılıma sahip olduğu kabul edilmiştir.

\subsection{Güvenilirlik Analizine İlişkin Bulgular}

Ölçeğe ilişkin güvenilirlik değerleri, SPSS 20 yazılımı aracılığıyla hesaplanan Cronbach'ın $\alpha$ katsayısıyla sınanmıştır. Tablo 6'da yer alan güvenilirlik analizi sonuçları incelendiğinde ölçeğe ilişkin $\alpha$ katsayısının 0,956 olarak hesaplandığı görülmektedir. Bu bağlamda ölçeğin güvenilir olduğu (Özdamar, 1999; Gliem ve Gliem, 2003) ve ileri analizlere geçilmesi noktasında bir sorun bulunmadığı sonucuna varılmıştır.

Tablo 5. Güvenilirlik analizi sonuçları

\begin{tabular}{ccccc}
\hline $\begin{array}{c}\text { Cronbach'ın } \alpha \\
\text { katsayısı }\end{array}$ & $\overline{\mathbf{x}}$ & $\boldsymbol{\sigma}^{2}$ & $\boldsymbol{\sigma}$ & Madde Sayıs1 \\
\hline 0,956 & 102,8378 & 193,752 & 13,91947 & 24 \\
\hline
\end{tabular}

\subsection{Açıklayıcı Faktör Analizine İlişkin Bulgular}

Bu çalışmada değişkenlerin tutarlılı̆̆ı Bartlett küresellik testi; örneklem hacminin yeterliğiyse Kaiser-MeyerOlkin (KMO) testi ile sınanmıştır. Analizler SPSS 20 yazılımı ile gerçekleştirilmiştir.

Tablo 6. Kaiser-Meyer-Olkin, Bartlett ve Uyum İyiliği Testleri

\begin{tabular}{lrr}
\hline Kaiser-Meyer-Olkin Testi (Örneklem Yeterliliği) & 0,953 \\
\hline Bartlett Küresellik Testi & Ki-Kare Değeri $\left(\chi^{2}\right)$ & 5480,273 \\
& Anlamlılık Düzeyi (p) & $0,000^{*}$ \\
\hline Uyum İyiliği Testi (UİT) & Ki-Kare Değeri $\left(\chi^{2}\right)$ & 493,202 \\
& Anlamlılık Düzeyi (p) & $0,000^{*}$ \\
\hline
\end{tabular}

${ }^{*} \mathrm{p}<0,001$

KMO değeri örneklem hacminin ölçülmek istenen yapıyı ölçme noktasında yeterli (KMO=0,953) olduğunu, Bartlett testi ise faktör analizinin uygulanabilir $\left(\chi^{2}=5480,273\right.$ ve $\left.p<0,001\right)$ olduğunu göstermektedir (Tablo 7). 
E. Bayraktaroğlu - O. Emir 13/4 (2021) 3873-3888

Bu bağlamda elde edilen sonuçlar incelendiğinde, örneklem yeterliliğinin, faktörleri tahmin etme noktasında yeterli olduğu, Bartlett ve Ui̇T testlerinin sonuçlarının ise istatistiki açıdan anlamlı olduğu görülmektedir.

Tablo 7. Faktörler ve Yüklerine İlişkin Desen Matrisi

\begin{tabular}{|c|c|c|c|c|}
\hline & \multicolumn{4}{|c|}{ Faktörler $^{\mathrm{a}}$} \\
\hline & İlgi & Sorumluluk & Merak & Güven \\
\hline i1 & 0,747 & & & \\
\hline i2 & 0,694 & & & \\
\hline i3 & 0,836 & & & \\
\hline i4 & 0,728 & & & \\
\hline i5 & 0,557 & & & \\
\hline i6 & 0,416 & & & \\
\hline s7 & & 0,462 & & \\
\hline s8 & & 0,832 & & \\
\hline s9 & & 0,801 & & \\
\hline s10 & & 0,741 & & \\
\hline s11 & & 0,538 & & \\
\hline s12 & & 0,481 & & \\
\hline m13 & & & 0,376 & \\
\hline m14 & & & 0,560 & \\
\hline m15 & & & 0,844 & \\
\hline m16 & & & 0,834 & \\
\hline m17 & & & 0,702 & \\
\hline m18 & & & 0,479 & \\
\hline g19 & & & & 0,351 \\
\hline g20 & & & & 0,426 \\
\hline g21 & & & & 0,583 \\
\hline g22 & & & & 0,840 \\
\hline g23 & & & & 0,790 \\
\hline g24 & & & & 0,690 \\
\hline$\lambda$ & 1,722 & 12,004 & 1,001 & 1,141 \\
\hline$\% \sigma^{2}$ & 7,174 & 50,099 & 4,173 & 4,752 \\
\hline$\sum \sigma^{2}$ & & & & \\
\hline
\end{tabular}

Türetme yöntemi: En büyük olabilirlik

Döndürme yöntemi: Kaizer normalizasyonuyla oblimin

a. Döndürme 9 yinelemede birleştirildi.

Faktörlere ilişkin desen matrisi incelendiğinde, kuramsal olarak tanımlanan faktör dağılımının gerçekleştiği görülmektedir (Tablo 8). Örneklem büyüklügünün 350 katılımcı olduğu durumlarda 0,30 ve üzeri faktör yüklerinin anlamlı olduğu kabul edilirken, örneklem büyüklüğünün 200 katılımcıya düştüğü durumlarda anlamlı kabul edilen yük sınırının 0,40'a düşürülmesi önerilmektedir (Hair vd., 2010). Bu çalışma kapsamında 339 katılımcıya ilişkin veriler analize alınmıştır. Faktör yükleri incelendiğinde g19 maddesi $(0,351)$ haricinde 0,40'ın altında bir faktör yükü hesaplanmamıştır. Bu bağlamda faktör yüklerinin anlamlı olduğu sonucuna varılmıştır. Yine faktörlerin özdeğerleri incelendiğinde, 1 'in altında $(\lambda<1)$ özdeğere sahip bir faktör olmadığ1 görülmektedir. Bu durum faktörlerin anlamlı olarak dağıldığını göstermektedir. Analiz sonucunda elde edilen dört faktörlü yapının, toplam varyansın \%66'sını açıkladığı görülmüştür. Bu sonuçlar hem yapılan analizlerin anlamlı olduğunu hem de kuramla uyumunu ifade etmektedir.

Tablo 8. Faktörlere ilişkin güvenilirlik analizi sonuçları

\begin{tabular}{cccccc}
\hline Faktör & $\begin{array}{c}\text { Cronbach'in } \boldsymbol{\alpha} \\
\text { katsayısı }\end{array}$ & $\overline{\mathbf{x}}$ & $\boldsymbol{\sigma}^{\mathbf{2}}$ & $\boldsymbol{\sigma}$ & Madde Sayısı \\
\hline İlgi (i) & 0,892 & 24,899 & 18,386 & 4,287 & 6 \\
\hline Sorumluluk (s) & 0,903 & 26,253 & 15,575 & 3,946 & 6 \\
\hline Merak (m) & 0,882 & 25,531 & 14,782 & 3,844 & 6 \\
\hline Güven (g) & 0,884 & 26,153 & 14,5221 & 3,810 & 6 \\
\hline
\end{tabular}


Faktörlere ilişkin güvenilirlik analizi sonuçlarına göre tüm faktörlere ilişkin güvenilirlik katsayıları yüksek güvenilirlik aralığındadır (Tablo 9). Bu bağlamda ölçeğin güvenilir olduğu (Özdamar, 1999; Gliem ve Gliem, 2003) ve DFA'ya geçilmesi noktasında bir sorun bulunmadığı sonucuna varılmıştır.

\subsection{Doğrulayııı Faktör Analizine İlişkin Bulgular}

AFA sonucunda elde edilen olumlu bulgular sonucunda, yapının DFA'ya tabi tutulmasına karar verilmiştir. $\mathrm{Bu}$ amaçla AMOS 24 yazılımı aracılığıyla DFA gerçekleştirilmiştir. Bu bağlamda önerilen modifikasyonlar hata değişkenlerine uygulanmıştır. DFA'nın gerçekleştirilmesi amacıyla oluşturulan model Şekil 1'de sunulmuştur.

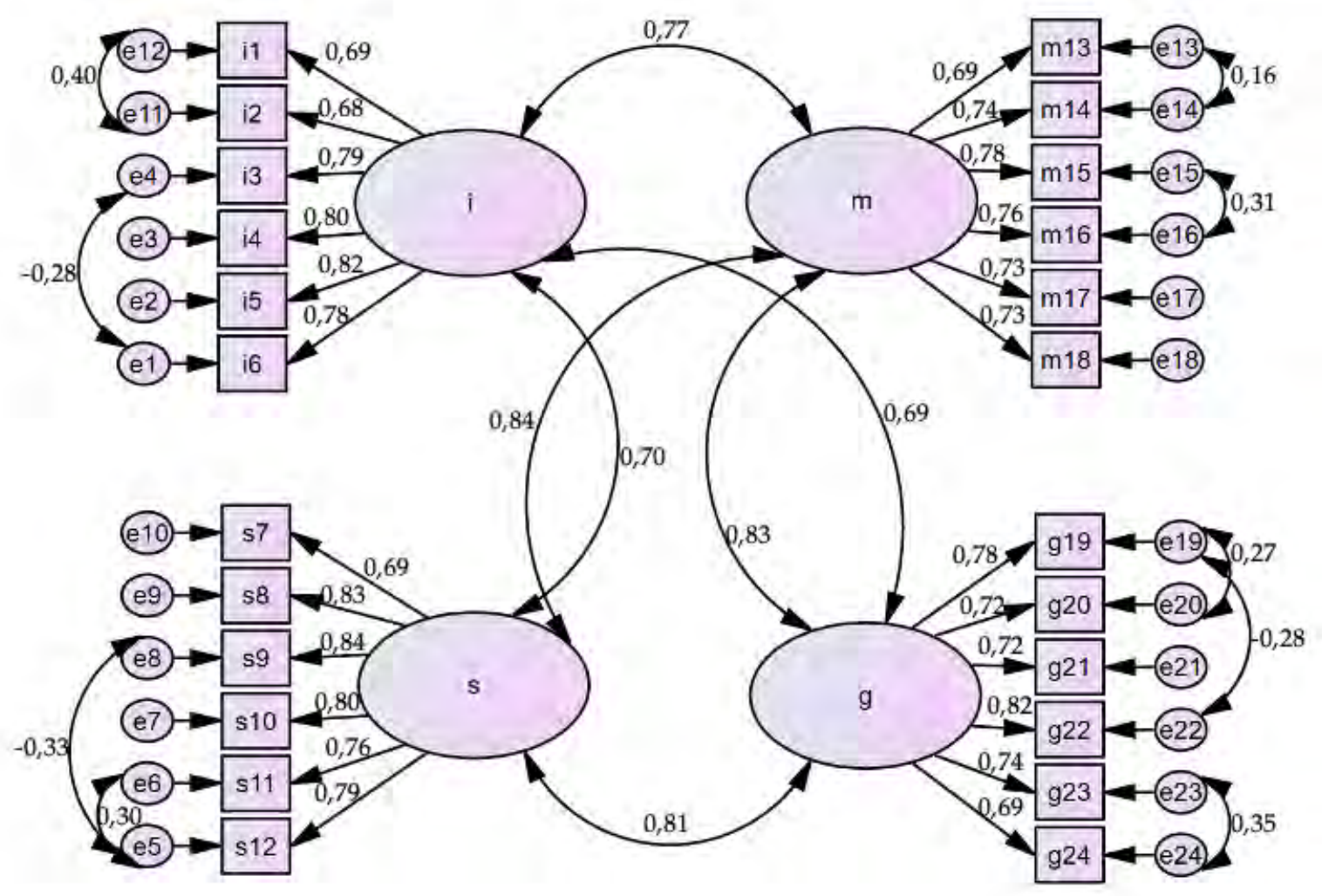

Şekil 2. Kariyer uyum yeteneği ölçeği için oluşturulan DFA modeli $\left(x^{2}=470,484\right.$; sd= 237)

DFA sonucunda ortaya çıkan model üzerinde öncelikle örtük değişkenleri oluşturan faktör yükleri değerlendirilmiştir. Bu bağlamda ilgi değişkeninin alt değişkenlerinin faktör yükleri 0,68 ile 0,82 arasında, merak değişkeninin alt değişkenlerinin faktör yükleri 0,69 ile 0,78 arasında, sorumluluk değişkeninin alt değişkenlerinin faktör yükleri 0,69 ile 0,84 arasında, güven değişkeninin alt değişkenlerinin faktör yükleri 0,69 ile 0,82 arasında çıktığı görülmüştür. Yakalanan bu yükler olumlu olarak yorumlanmış ve uyum endekslerinin değerlendirilmesine geçilmiştir.

Tablo 9. Uyum Endeksleri

\begin{tabular}{|c|c|c|c|c|c|c|c|c|c|c|c|c|}
\hline$\chi^{2 / s d}$ & AGFI & RMSEA & SRMR & NFI & TLI & CFI & GFI & RFI & IFI & PGFI & PNFI & $\mathrm{p}$ \\
\hline 1,985 & 0,873 & 0,054 & 0,044 & 0,916 & 0,949 & 0,956 & 0,90 & 0,903 & 0,957 & 0,711 & 0,787 & $0,000^{*}$ \\
\hline
\end{tabular}

DFA sonucunda elde edilen uyum endeksleri incelendiğinde $\chi^{2} / \mathrm{sd}$, SRMR, CFA, IFI, PGFI kriterlerinin çok iyi uyum aralığında gerçekleştiği görülmüştür. Bununla birlikte AGFI, RMSA, NFI, TLI, GFI, RFI kriterlerinin de kabul edilebilir uyum aralığında gerçekleştiği saptanmıştır (Tablo 10 ve Tablo 3). Bu sonuçlar, gerçekleştirilen DFA sonucunda, elde edilen modelin uygulanabilir olduğunu ve uyarlanan ölçeğin kullanılabilir olduğunu ifade etmektedir. 


\section{SONUÇ VE TARTIŞMA}

Savickas ve Porfelli (2013) tarafından bireylerin kariyer uyum yeteneklerini ölçmek amacıyla geliştirilen ölçeğin Türkçeye ve Türkiye kültürüne uyarlanmasını amaçlayan bu çalışma kapsamında yapı eşdeğerliği, dilsel ve kültürel eşdeğerliği ve ölçüm eşdeğerliği sınanan ölçeğin, konaklama işletmeleri çalışanları üzerinde uygulanması noktasında güvenilir ve geçerli bir ölçüm aracı olduğu sonucunda varılmıştır. Bu bağlamda 24 madde ve 4 faktörden oluşan özgün ölçek yapısı aynı şekliyle korunmuş, Türkiye kültürü kapsamında Türkçeye çevirisi gerçekleştirilerek kültürel ve dilsel eşdeğerliği sağlanmıştır. Çalışma kapsamında uyarlanan soru formu, gerçekleştirilen saha çalışması yoluyla, 339 otel çalışanı üzerinde uygulanmış ve elde edilen veriler ölçüm eşdeğerliği için analize tabi tutulmuştur. Yapılan AFA sonucunda, özgün ölçeğin faktör yapısının, çalışma kapsamında ulaşılan örneklemde de aynı şekilde ortaya çıktığı görülmüştür. Yapılan DFA sonucunda ise, uyarlanan Türkçe formun, ölçülmek istenen yapıyı ölçme noktasında geçerli ve güvenilir bir araç olduğu sonucuna ulaşılmıştır.

Çalışma ile uyarlanan soru formunun, farklı örneklemler ile turizm endüstrisinin diğer sektörlerinde de uygulanması önerilmektedir. Kariyer uyum yeteneğinin, kariyer stresi, kariyer kaygısı, kariyer geleceği, kariyer engelleri, kariyer tatmini, kariyer bağlılığı, kariyer planlaması gibi kavramlarla ilişkilerinin incelenmesinin, genel olarak kariyer çalışmalarına katkıda bulunacağı ve yeni bakış açıları geliştirilmesine yardımcı olacağı düşünülmektedir. Bununla birlikte kariyer uyum yeteneği iş tatmini ve örgütsel öğrenme konuları arasındaki ilişkilerin incelenmesinin de gelecekteki çalışmalar için bir yol haritası olarak değerlendirilebileceği öngörülmektedir.

Araştırma kapsamında uyarlanan ölçeğin gösterdiği yüksek uyum, ölçeğin çeşitli diğer iş kollarında da uygun sonuçlar verme potansiyeli taşıdığını göstermektedir. Bu bağlamda bilimsel anlamda değerlendirilecek ölçeğin, mesleki uygulamalarda, özellikle de insan kaynakları yönetimi alanında başvurulabilecek bir ölçüm aracı olarak değerlendirilebileceği düşünülmektedir. Kariyer uyum yeteneğinin yüksekliğinin, çalışanların yeni işkolları ve yeni iş yerlerine uyum sürecini hızlı şekilde atlatmalarına yardımcı olduğu, son zamanlarda yazında en öne çıkarılan noktalardan birisidir (Lodi vd., 2020; Chen vd., 2020; Xu vd., 2020; Hlad' o, Kvasková ve Ježek, 2020; Qiao ve Huang, 2019). Bu bağlamda, özellikle konaklama sektörü gibi iş gücü devir oranı yüksek olan sektörlerde çalışan seçimi, işe alma ve işe alıştırma noktalarında kariyer uyum yeteneğinin göz önüne alınmasının, bahsedilen faaliyetlerde karşılaşılan maliyetlerin düşürülmesine yardımcı olacağ öngörülmektedir. Bununla birlikte, eğitim kurumlarının da eğitim müfredatlarını belirlerken, kariyer uyum yeteneğini arttırmaya yönelik faaliyetleri müfredatlarına yedirmelerinin, öğrencilerin mezuniyetlerine kadar olan süreçte iş dünyasına daha hazır şekilde yetiştirilmelerine yardımcı olacağı düşünülmektedir.

Çalışmada karşılaşılan en önemli sınırlılık olarak ise, örneklem yöntemi olarak seçilen uygun örneklemenin dezavantajları görülmektedir. Bu noktada uygun örnekleme zamanla ilgili ve maddi olan maliyetleri en aza düşürmek için başvurulan bir örnekleme yöntemidir (Balc1, 2013: 103). Fakat çalışmanın en önemli amacının ölçüm aracının uyarlanması olduğu düşünüldüğünde, örneklemin bu amaçlar doğrultusunda yeterli bilgiyi sunacağı düşünülmüştür. Çalışma kapsamında karşılaşılan bir diğer sınırlık olarak, örneklemin turizm endüstrisinin konaklama sektöründe çalışan bireyleri kapsıyor oluşudur. Bu sınırlığın, çalışma amaçlarına zarar vermeyeceği öngörülmüştür. Bununla birlikte ilerleyen dönemde turizm endüstrisinin farklı sektörlerinden elde edilen örneklemlerle ve diğer endüstri kollarından elde edilecek örneklemlerle bu ölçeğin tekrar tekrar sınanmasının faydalı olacağı düşünülmektedir.

\section{KAYNAKÇA}

Balc1, A. (2013). Sosyal Bilimlerde Araştırma: Yöntem, Teknik ve Illkeler (10 Bs.), Ankara, Pegem Yayınc1lık.

Beaton, D.E., Bombardier, C., Guillemin, F. ve Ferraz, M.B. (2000). Guidelines for the Process of Cross-Cultural Adaptation of Self-Report Measures, Spine, 25 (24), 3186-3191.

Bentler, P.M. ve Yuan, K.H. (1999). Structural equation modeling with small samples: Test statistics, Multivariate Behavioral Research, 34 (2), 181-197.

Brown, T.A. (2015). Confirmatory Factor Analysis for Applies Research (2. Bs.). New York, The Guilford Press.

Büyüköztürk, Ş. (2002). Faktör Analizi: Temel Kavramlar ve Ölçek Geliştirmede Kullanımı, Kuram ve Uygulamada Ĕ̆itim Yönetimi, 32, 470-483. 
E. Bayraktaroğlu - O. Emir 13/4 (2021) 3873-3888

Caramelli, M. ve Van de Vijver, F.J.R. (2013). Towards a Comprehensive Procedure for Developing Measurement Scales for Cross-Cultural Management Research. International Management, 17(2), 150163.

Chen, H., Fang, T., Liu, F., Pang, L., Wen, Y., Chen, S. ve Gu, X. (2020). Career Adaptability Research: A Literature Review with Scientific Knowledge Mapping in Web of Science, International Journal of Environmental Research and Public Health, 17, 5986.

Chen, X., Xingying, G., Wanyan, F., Yanjun, X., Haiyan, X., Wenjing, C. ve Min, L. (2020). The role of career adaptability and resilience in mental health problems in Chinese adolescents, Children and Youth Services Review, 112, 1048932.

Dufy, R.D. (2010). Sense of Control and Career Adaptability Among Undergraduate Students, Journal of Career Assessment, 18(4), 420-430.

Dwyer, L., Gill, A. ve Seetaram, N. (2012). Handbook of Research Methods in Tourism: Quantitative and Qualitative Approaches, Cheltenham, Edward Elgar Publishing Limited.

Epstein, J., Santo, R.M. ve Guillemin, F. (2015). A review of guidelines for cross-cultural adaptation of questionnaires could not bring out a consensus, Journal of Clinical Epidemiology, 68 (4), 435-441.

Falcão, D.D.M., Ciconelli R.M. ve Ferraz, M.B. (2003). Translation and cultural adaptation of quality of life questionnaires: an evaluation of methodology, The Journal of Rheumatology, 30, 379-385.

George, D. ve Mallery, M. (2010). SPSS for Windows Step by Step: A Simple Guide and Reference, 17.0 update (10. Bs.), Boston, Pearson.

Gliem, J. ve Gliem, R. (2003). Calculating, interpret ing, and reporting Cronbach's Alpha Reliability Coefficient for Likert-type scales, Midwest Research-to-Practice Conference in Adult, Continuing, and Community Education, Erişim Tarihi: 18 Eylül 2021, URL: https://scholarworks.iupui.edu/bitstream/handle/1805/344/Gliem\%20\%26\%20Gliem.pdf?sequence=1 \&isAllowed $=\mathrm{y}$

Güney, S. (2014). İnsan Kaynakları Yönetimi, Ankara, Nobel Akademik Yayıncılık.

Gürsakal, N. (2009). Çıkarımsal İstatistik Minitab-SPSS Uygulamalı (4. Bs), Dora, Bursa.

Hair, J.F., Black, W.C., Babin, B.J. ve Anderson, R.E. (2009). Multivariate Data Analysis (7. Bs.), New Jersey, Prentice Hall.

Hamtiaux, A., Houssemand, C. ve Vrignaud, P. (2013). Individual and Career Adaptability: Comparing Models and Measures, Journal of Vocational Behavior, 83 (2), 130-141.

Harkness, J.A. (2003). Questionnaire translation, Harkness, J.A., Van de Vijver, F.J.R. ve Mohler, P. (Ed.), Crosscultural survey methods, New York, Wiley, 35-56.

Harrington, D. (2009). Confirmatory Factor Analysis, New York, Oxford University Press.

Herdman, M., Fox-Rushby, J. ve Badia, X. 'Equivalence' and the translation and adaptation of health-related quality of life questionnaires, Quality of Life Research, 6, 237-247.

Hirschi, A. ve Vondracek, F.W. (2009). Adaptation of career goals to self and opportunities in early adolescence, Journal of Vocational Behavior, 75, 120-128.

Hlad'o, P., Kvasková, L., Ježek, S., Hirschi, A. ve Macek, P. (2020). Career Adaptability and Social Support of Vocational Students Leaving Upper Secondary School, Journal of Career Assessment, 28(3), 478-495.

Hui, C.H., ve Triandis, H.C. (1985). Measurement in Cross-Cultural Psychology: A Review and Comparison of Strategies, Journal of Cross-Cultural Psychology, 16(2), 131-152.

İlhan, M. ve Çetin, B. (2014). LISREL ve AMOS Programları Kullanılarak Gerçekleştirilen Yapısal Eşitlik Modeli (YEM) Analizlerine İlişkin Sonuçların Karşılaştırılması, Journal of Measurement and Evaluation in Education and Psychology, 5 (2), 26-42. 
E. Bayraktaroğlu - O. Emir 13/4 (2021) 3873-3888

Kalafat, T. (2012). Kariyer Geleceği Ölçeği (KARGEL): Türk Örneklemi İçin Psikometrik Özelliklerinin İncelenmesi, Türk Psikolojik Danışma ve Rehberlik Dergisi, 4 (38), 169-179.

Koller, M., Aaronson, N.K., Blazeby, J., Bottomley, A., Dewolf, L., Fayers, P., Johnson, C., Ramage, J., Scott, N. ve West, K. (2007). Translation procedures for standardised quality of life questionnaires: The European Organisation for Research and Treatment of Cancer (EORTC) approach, European Journal of Cancer, 43 (12), 1810-1820.

Lodi, E., Zammitti, A., Magnano, P., Patrizi, P. ve Santisi, G. (2020). Italian Adaption of Self-Perceived Employability Scale: Psychometric Properties and Relations with the Career Adaptability and WellBeing, Behavioral Sciences, 10(5), 82.

Mulaik, S.A. (2010). Foundations of Factor Analysis (2. Bs.), Boca Raton, CRC Press.

Ömeroğlu, S. (2014). Polis Akademisi Öğrencilerine Yönelik Kariyer Uyumu Programının Etkililiğinin Değerlendirilmesi (Yayımlanmamış Yüksek Lisans Tezi), Ankara Üniversitesi Eğitim Bilimleri Enstitüsü, Ankara.

Özdamar, K. (1999). Paket Programlar ile İstatistiksel Veri Analizi (2. Bs.), Eskişehir, Kaan Kitabevi.

Özdamar, K. (2010). Paket Programlar ile İstatistiksel Veri Analizi 2 - Çok Değişkenli Analizler (7. Bs.), Eskişehir, Kaan Kitabevi.

Özdamar, K. (2011). Paket Programlar ile İstatistiksel Veri Analizi 1 - Minitab 15, PASW 18 (8. Bs), Eskişehir, Kaan Kitabevi.

Perneger, T.V., Leplège, A. ve Etter, J.F. (1999). Cross-cultural adaptation of a psychometric instrument: two methods compared, J Clin Epidemiol, 52, 1037-1046.

Pett, M.A., Lackey, N.R. ve Sullivan, J.J. (2003). Making sense of factor analysis, California, SAGE Publications, Inc.

Qiao, X. ve Huang, J. (2019). Effect of College Students' Entrepreneurial Self-Efficacy on Entrepreneurial Intention: Career Adaptability as a Mediating Variable, International Journal of Educational Methodology, 5 (3), 305-313.

Russell, D.W. (2002). In Search of Underlying Dimensions: The Use (and Abuse) of Factor Analysis in Personality and Social Psychology Bulletin, Personality and Social Psychology Bulletin, 28 (12), 1629-1646.

Savickas, M.L. (1997). Career Adaptability: An Integrative Construct for Life-Span, Life-Space Theory, The Career Development Quarterly, 45 (3), 247-259.

Savickas, M.L. (2005). The theory and practice of career construction. Lent, R.W. ve Brown, S.D. (Ed.), Career development and counseling: Putting theory and research to work, New Jersey, John Wiley \& Sons, 42-70.

Savickas, M.L., Nota, L., Rossier, J., Dauwalder, J.P., Duarte, M.E., Guichard, J., Soresi, S., Van Esbroeck, R. ve van Vianen, A.E.M. (2009). Life designing: A paradigm for career construction in the 21st century, Journal of Vocational Behavior, 75, 239-250.

Savickas, M.L., ve Porfeli, E.J. (2012). Career Adapt-Abilities Scale: Construction, Reliability, and Measurement Equivalence Across 13 Countries, Journal of Vocational Behavior, 80, 661-673.

Skorikov, V. (2007). Continuity in adolescent career preparation and its effects on adjustment, Journal of Vocational Behavior, 70, 8-24.

Super, D.E. ve Knasel, E.G. (1981). Career Development in Adulthood: Some Theoretical Problems and a Possible Solution, British Journal of Guidance and Counselling, 9 (2), 194-201.

Şencan, H. (2005). Sosyal ve Davranışsal Ölçümlerde Güvenilirlik ve Geçerlilik, Ankara, Seçkin Yayınları

Tabachnick, B.G. ve Fidell, L.S. (2013). Using Multivariate Statistics (6. Bs.), Pearson, Boston.

Taşlıyan, M., Arı, N.Ü. ve Duzman, B. (2011). İnsan Kaynakları Yönetiminde Kariyer Planlama ve Kariyer Yönetimi: İ̈BF Öğrencileri Üzerinde Bir Alan Araştırması, Organizasyon ve Yönetim Bilimleri Dergisi, 3 (2), 231-241. 
E. Bayraktaroğlu - O. Emir 13/4 (2021) 3873-3888

Tolentino, L.R., Garcia, P.R.J.M., Lu, V.N., Restubog, S.L.D., Bordia, P., ve Plewa, C. (2014). Career Adaptation: The Relation of Adaptability to Goal Orientation, Proactive Personality, and Career Optimism, Journal of Vocational Behavior, 84, 39-48.

Tortop, N., Aykaç, B., Yayman, H. ve Özer, M.A. (2006). İnsan Kaynakları Yönetimi, Ankara, Nobel Yayın Dağıtım.

Uğur, A. (2008). İnsan Kaynakları Yönetimi, Sakarya, Sakarya Yayıncılık.

Usunier, J.C. (2011). Language as a resource to assess cross-cultural equivalence in quantitative management research, Journal of World Business, 46 (3), 314-319.

Yaşlığlu, M.M. (2017). Sosyal Bilimlerde Faktör Analizi ve Geçerlilik: Keşfedici ve Doğrulayıcı Faktör Analizlerinin Kullanılması, İstanbul Üniversitesi İ̧sletme Fakültesi Dergisi, 46, 74-85.

Yousefi, Z., Abedi, M., Baghban, I., Eatemadi, O. ve Abedi, A. (2011). Personal and Situational Variables, and Career Concerns: Predicting Career Adaptability in Young Adults, The Spanish Journal of Psychology, 14 (1), 263-271.

Yüksel, Ö. (2000). İnsan Kaynakları Yönetimi, Ankara, Gazi Kitabevi. 
E. Bayraktaroğlu - O. Emir 13/4 (2021) 3873-3888

\section{Ek 1 - Çalışma Kapsamında Kullanılan Soru Formu}

Değerli katılımcı,

Bilimsel bir araştırmanın parçası olan bu soru formu ile hizmet endüstrisi çalışanlarının kariyer uyum yetenekleri ile iş memnuniyeti arasındaki ilişkilerin ölçülmesi amaçlanmaktadır. Bu formu aşağıda verilen yönlendirmeler 1şı̆̆ında doldurmak suretiyle çalışmaya vermiş olduğunuz destekten ötürü teşekkür ederiz.

Saygilarımızla,

Dr. Öğretim Üyesi Engin Bayraktaroğlu

Anadolu Üniversitesi Turizm Fakültesi

Prof. Dr. Oktay Emir

Anadolu Üniversitesi Turizm Fakültesi

Tel:

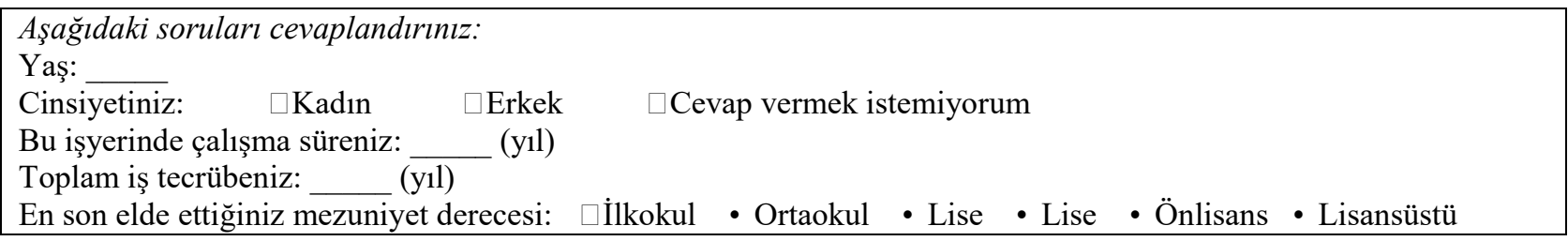

\begin{tabular}{|c|c|c|c|c|c|c|}
\hline \multicolumn{7}{|c|}{$\begin{array}{l}\text { Kişiler kariyerlerini olv } \\
\text { yönlerini diğer yönlerin } \\
\text { olduğunda ne derece gü } \\
\mathbf{5}=\text { Son Derece Güçlü } \\
\mathbf{4}=\text { Çok Güçlü } \\
\mathbf{3}=\text { Güçlü } \\
\mathbf{2}=\text { Biraz Güçlü } \\
\mathbf{1}=\text { Güçsüz }\end{array}$} \\
\hline 1 & Geleceğin nasıl olacağ1 üzerine düşünme & 5 & 4 & 3 & 2 & 1 \\
\hline 2 & Yapılan seçimlerin geleceği şekillendirdiğinin farkında olma & 5 & 4 & 3 & 2 & 1 \\
\hline 3 & Gelecek için hazırlık yapma & 5 & 4 & 3 & 2 & 1 \\
\hline 4 & Yapılması gereken eğitim ve kariyer seçimlerinin farkında olma & 5 & 4 & 3 & 2 & 1 \\
\hline 5 & Hedeflere nasıl ulaşılacağına yönelik planlama yapma & 5 & 4 & 3 & 2 & 1 \\
\hline 6 & Kariyer üzerinde düşünme & 5 & 4 & 3 & 2 & 1 \\
\hline 7 & İyimser olmaya çalışma & 5 & 4 & 3 & 2 & 1 \\
\hline 8 & Kendi kararlarını kendisi verme & 5 & 4 & 3 & 2 & 1 \\
\hline 9 & Yapılan hareketlerin sorumluluğunu üstlenme & 5 & 4 & 3 & 2 & 1 \\
\hline 10 & İlkelerini savunma & 5 & 4 & 3 & 2 & 1 \\
\hline 11 & Kendine güvenme & 5 & 4 & 3 & 2 & 1 \\
\hline 12 & Kendisi için en doğru olanı yapma & 5 & 4 & 3 & 2 & 1 \\
\hline 13 & Çevreyi keşfetmeye çalışma & 5 & 4 & 3 & 2 & 1 \\
\hline 14 & Birey olarak gelişme noktasında firsatları kollama & 5 & 4 & 3 & 2 & 1 \\
\hline 15 & Bir seçim yapmadan önce seçenekleri araştırma & 5 & 4 & 3 & 2 & 1 \\
\hline 16 & Bir şeyleri yapmanın farklı yollarını inceleme & 5 & 4 & 3 & 2 & 1 \\
\hline 17 & Akıldaki sorular üzerinde derinlemesine düşünme & 5 & 4 & 3 & 2 & 1 \\
\hline 18 & Yeni firsatlar konusunda meraklı olma & 5 & 4 & 3 & 2 & 1 \\
\hline 19 & Verilen görevleri verimli bir şekilde gerçekleştirme & 5 & 4 & 3 & 2 & 1 \\
\hline 20 & İşleri iyi bir şekilde yapmaya özen gösterme & 5 & 4 & 3 & 2 & 1 \\
\hline 21 & Yeni beceriler edinme & 5 & 4 & 3 & 2 & 1 \\
\hline 22 & Sahip olunan becerileri geliştirme & 5 & 4 & 3 & 2 & 1 \\
\hline 23 & Engelleri aşma & 5 & 4 & 3 & 2 & 1 \\
\hline 24 & Sorun çözme & 5 & 4 & 3 & 2 & 1 \\
\hline
\end{tabular}

